\title{
The Calling of the Unspeakable and the Seduction of Metamorphosis: Vergílio Ferreira, From Literature to FILM
}

\author{
L. Cardoso and T. Mendes
}

\begin{abstract}
Vergílio Ferreira, one of the most important portuguese writers of the XX century, has a path of crossroads and parallel thoughts about the intersemiotic relations between Literature and Cinema. Starting with a clear separation of novels from films, the writer slowly changes his path of reffusal towards a metamorphosis that seduces him into the cinema and its calling of the unspeakable.
\end{abstract}

Keywords - Adaptation, Cinema, Literature, Vergílio Ferreira.

\section{INTRODUCTION}

The empirical and metaphysical path of Vergílio Ferreira can be embodied in a verb that systematizes and unifies the plurality of his being: to think. Pensar is also the title of one of his diaristic productions that exemplifies the extent to which the word of Vergílio Ferreira encodes and invokes literary and philosophical roots, in permanent search for himself in the ephemerality of the moment that the spelling crystallizes.

Between the ephemeral and the perennial, the being and the existing, Vergílio Ferreira consolidated his literary framework, from Neo-Realism to Existentialism. In the dialogue between Literature and Cinema, these movements illustrate different symbioses to which many writers have not been indifferent (André Malraux, one of Vergílio Ferreira's cortical influences is a striking example).

In 1993, in the text Vergílio Ferreira and Cinema (António, 1995, pp. 69-80), the director Lauro António reflects, with an interesting and innovative point of view, on the Portuguese writer, emphasizing the plurality of relations between Literature and Cinema that he shows in his life and literary writings. The filmmaker, a man of the film industry but also a critic, was able to gather, from his personal contact, from his readings and from his experience as responsible for the adaptation of the novel

Manhã Submersa to the screen, a set of vergilian connections between word and image. Lauro António, in relation to Vergílio Ferreira, identifies four main links between Literature and Cinema: the writer's comments on cinema, integrated in his Conta-Corrente, the close monitoring of the

L. Cardoso is with the Polytechnic Institute of Portalegre (Portugal) with the Department of Languages and Communication

T. Mendes is with the Polytechnic Institute of Portalegre (Portugal) with the Dep. of Languages and Communication transposition to the screen of his works (Cântico Final and Manhã Submersa), the writing of texts for documentaries, and his experience as an actor in the film Manhã Submersa (1980). To these elements we will add a fifth: the production of essayistic texts with a thematic focus on cinema.

In this pentagon of relations with the Cinema, Vergílio Ferreira revealed a slow evolution initiated in an irreducible distance, towards the seduction of the eternity, promised by the screen. In this metamorphosis by the mirror, the (re) discovery of Vergílio Ferreira illuminates the relations between Literature and Cinema in Portugal.

At a key moment in the novel, the narrator, in flashback, recalls the day when he woke up and looked at the mirror: "Before me was a person who looked at me with a whole individuality who lived in me and I did not know. I approached, fascinated, looked closely. And I saw, I saw the eyes, the face of someone who inhabited me, who was me and I never imagined." It is precisely through the gaze that the alarm is given to existence, to the reality of being and being alive. It is in this dialogue in the mirror that the narrator finds himself between the word and the image. In a similar way, it is also in the mirror that we must perceive the writing of Vergílio Ferreira, not only because his words are his mirror as a man, but also because it is his image of man that inspires him to create his words. Moreover, this writer reveals dialogues between word and image, both as novelist and essayist that can be characterized as a true metamorphosis to the mirror in seduction for eternity.

This vergilian dialogue between literature and cinema has a first face in the set of films and documentaries: Vergílio Ferreira in a «Manhã Submersa» (Manuel Guimarães, 1975), Preface to Vergílio Ferreira (Lauro António, 1975), Manhã Submersa (Lauro António, 1979), Manhã Submersa (Lauro António, 1980), and Mother Genoveva (Lauro António, 1983). In addition to the aforementioned adaptations and documentaries, we must also remember that, in 1973, Quirino Simões intended to adapt the novel Alegria Breve; in 1978, Varela Silva wanted to adapt the novel Aparição; and in 1988, the german director Wolf Gaudlitz, competing with Lauro António, managed to acquire the right to adapt the novel Até ao Fim, which did not materialize into a film.

In addition to the films Cântico Final and Manhã Submersa, Vergílio Ferreira started a dialogue between the word and the image in all the aesthetic objects we refer to. Preface to Vergílio Ferreira, made by Lauro António, marks the first contact between Vergílio Ferreira and the person responsible for 
adapting the novel Manhã Submersa to the screen. The purpose of this documentary was to present the writer and his work, the director having used only the memory he had of the author's writing and without planning "to find in a new expressive medium the rhythm of his sentences, the color of the word, the resonance of obsessions. " (Lauro António, 1995, p. 72).

The dialogue between Lauro António and Vergílio Ferreira was resumed in 1979 with «Vergílio Ferreira in a «Manhã Submersa». This documentary was initially thought of as an extensive interview with the writer in order to focus on the novel and its connection to the spaces that were portrayed in it, but as the director claims, when Vergílio Ferreira found in the old seminary several families who returned from the former Portuguese colonies, passed from interviewee to interviewer. In this way, the documentary also witnessed a moment in the history of Portugal, just as the novel had done.

In 1983, Lauro António adapts the story Mother Genoveva for a series that would be transmitted in RTP-2, transposing the action of Beira Alta to the Alentejo, putting "off the screen" the violent moments, trying to be faithful to the spirit - first intention of the director of the vergilian work - but also to the narrative structure, in an exercise of formal austerity and clear dispossession. The deliberate options of the director reveal a deep respect for the author and for his literary production, which leads him to an attitude of fidelity of creation, resulting in an aesthetic object that pleased Vergílio Ferreira, as we can read in its Conta-Corrente.

The connections between Lauro António and Vergílio Ferreira reach their highest point when the novel Manhã Submersa is transposed to the screen. In this film, besides being very close to the director and the process of adaptation of his novel, Vergílio Ferreira also plays a character as an actor. Vergílio Ferreira not only accepted the invitation of Lauro António to be close to the film, but also accepted to represent the role of dean of the seminary. Integrating this project, it ceases to be an observer outside the adaptation process to become an element of the process itself, which implies that the film also illustrates its contribution and, moreover, counts on its consent.

In this universe of relations, Mário Jorge Torres, analyzing the connections of Vergílio Ferreira with cinema, identifies two moments: a "resistance to the image" and a "desire of the image" (Torres, Mário, 1995, pp. $501-510$ ) It is a gradual process that has its highest attraction with the adaptations of the novels and that will follow it throughout its romanesque production. In fact, besides integrating cinematographic narrative techniques in his novels, the author of Em nome da terra still resorts to cinema as a metaphor. He uses the seventh art to describe the process of remembrance through a multiplicity of succeeding images, but which in an over-printing effect reveal the one that is the main one ("The images come to me in vortex, did not I say it already? But there is always one that comes on top of the others and it is you. Very fast energetic energy, over other images - so many "); tries to describe the discourse with a cinematographic technique, using a concept to explain the meaning of its vision of the real; and describes the temporality with explicit recourse to the film as a term of comparison ("It is the time when words no longer create the world as in the mouth of God that created it with them.") When he realizes that they no longer bring anything I go with you, you take the son, we cross the time, like a film shot back.”(Torres, Mário, 1995, pp. 115).

In 1975, Vergílio Ferreira published in Colóquio-Letras magazine an article entitled "The Book, the Movie, the Time", that would later appear in Espaço do Invisivel III. The author begins this text with an issue that is at the same time a statement: "Why does it age earlier, and in general, a film than a book?". One glimpse of his opinion is immediately apparent: the book remains. A second relevant essay for this problem is published in the second volume of Espaço do Invisível.

In "Kafka, an aesthetics of the dream," the "image resistance" is clear, since the film of Orson Welles is seen as disappointing. By contrast, the book reveals itself in this new reading of 'fabulous grandeur' (Ferreira, V., 1993, p. 43) which reiterates an idea by the writer that revisiting a book is manifestly different from reviewing a film, since the first action means, as we have already said, a moment of fascination. Vergílio Ferreira emphasizes that pleasure and fascination are, above all, experiences only associated with the book.

A third article dedicated to the cinema, "From book to film", published in the fourth volume of Espaço do Invisivel, and also in the fourth edition of Cântico Final, begins the phase that Mário Jorge Torres calls "desire of the image". It is a text that focus the adaptation of his novel by Manuel Guimarães and that would become his first concrete experience with the cinematographic universe. Reflecting on the main difficulty in transposing a novel, the writer tells us: "Immediately this problem in a film is determined radically in the winding path that passes between what is told by the image and the unspeakable that is sought - between the irreducibility of what is shows us on the screen and the report of the imaginative construction operated on a book. Where a book tells, the movie shows".

Besides the literary and philosophical questions, one of the main problems of the film is the political layer that Manuel Guimarães applied. The writer emphasizes that his disagreement with the options taken is due more to the fact that the political nuance does not respect the overall metaphysical atmosphere of the written text, rather than its ideological value. So Vergílio Ferreira considers that the adaptation was both faithful and creative: "Thus, from the book to the film, I do not feel that something fundamental was lost for the intention with which I wrote it - as I feel that something new has been created beyond the art of the image in which it is transfigured." (Ferreira, V., 1993, p. 43). All that the writer had in mind when he wrote the book was reflected in the film and this, he says, can compensate for the gaps in adaptation.

Vergílio Ferreira was not a regular movie spectator, as evidenced by the sparse and brief references he wrote about the seventh art in Conta-Corrente. It is that the author only had as main motivation to see a film: the confirmation or refutation of 
critical opinions that the film already received. The great majority of his remarks are not a very good example of praise; moreover, it is ruled by profoundly unjust judgments. Vergilio Ferreira strongly criticized films such as Veronika Voss, Zelig, The Last Tango in Paris, The Mystery of Oberwald, and refuted aspects of Citizen Kane, which may lead us to consider the novelist as an irreducible opponent of cinema. However, the writer reveals an adequate aproach to La Luna, The Enraged Bull, Andrei Rubliov, Amadeus or The 4th Commandment. In his analysis, the writer has as main reason for analysing the narrative construction of the films and this concern leads some authors to consider that Vergílio Ferreira would not have been indifferent to the contact with these narrative film models. However, of the 2307 pages of the five volumes of the first series, only 87 times contemplate the universes of television and the cinema, which indicates the writer's lack of appreciation for the seventh art.

But the main element that the author comments belongs to the movie Manhã Submersa. It is the message of the mutilation of the protagonist (the young seminarian, knowing that cripples can not be priests, decides to grab a rocket in his hand until it explodes).Vergílio Ferreira emphasizes the outcome created by the director and establishes a counterpoint: while Lauro António closes the story with a hopeless message, the writer deliberately opted for a message of adaptation to a new life, reason why the director's options resulted in a subtle modification of the meaning of the novel. And he concludes the parallelism, until he invokes the opinion of Eduardo Lourenço: "I had in fact thought that it should be a simile of a closed and totalitarian society, as it is a fascist or communist society and it is after all the whole world. Lauro António, unconsciously perhaps, turned him into the image of what seems to be the seed of what is the deformaty of our whole Portuguese way of being. Not the religious way the way to be tout court. What happened in the seminaries was happening in all the houses of education and schools. The root of all our education, that is, deformation, is there. That is why Eduardo Lourenço told me that this is the most Portuguese film ever made and that if this is felt by us, that we live in this environment, it is particularly felt for those who are foreign." (Ferreira, V., 1993, p. 52).

The Nova Conta-Corrente Series establishes the removal of Vergílio Ferreira from the audiovisual sector and, more clearly, from cinema. The 1224 pages of the four volumes that continue the diaristic line of the author are rarely witnesses of writings on the mentioned theme.

In this dialogue between word and image in Vergílio Ferreira, we verified that it is established in the reflections of a peculiar mirror. For the writer the aesthetic predominance of the word on the image is unquestionable, but it nevertheless feels the attraction of seeing it transfigured in the mirror of the cinema, whether we consider its interest in adapting its novels, or evaluate an influence of the seventh art in his romanesque production.

We consider that the writer, although he was not a consistent cinephile, did not fail to consider cinema an interesting instrument for spreading the written word. From this premise, Vergilio Ferreira approached the image in different senses. From an absolute irreducibility, the writer transformed his connection to cinema into a desire for image, metamorphosing the initial refusal into selective and reticent perception, seeking only the reflection of writing on the screen. The cinema functioned as a mirror of literature, reflecting the common points - the narratological essence - and emphasising the inherent "misrepresentations" of the word transformed in the image. Still fully aware of this "misrepresentation" that affects the adaptation of a book, we believe that it has not ceased to feel the fascination for this space of the unspeakable that is the cinema. Moreover, Vergílio Ferreira may have sought in the big screen a bridge to his space of the unspeakable, an instrument for understanding, an element capable of assisting the word in attempting to express the world that it often fails to translate.

In this quest for the image, he found the examples of Malraux, the Nouveau Roman and the Nouveau Cinéma, and even Neo-Realism that explored lines of convergence between the novel and the film. Throughout its literary and ideological evolution it did not deliberately seek an enrichment of its narrative texture through cinematographic techniques, but an approximation can not be denied. On the one hand, we can't speak of a "cinematographic writing" in Vergílio Ferreira, but on the other hand, we can not ignore the points of contact between his writing and the cinema. In fact, we believe that Vergílio Ferreira's romanesque production does not exhibit a repository of characteristics that systematically illustrates an explicit apprehension of film techniques, so in this perspective it would not be scientifically correct to identify a deliberate and consistent cinematographic writing in this author. Nevertheless, this impossibility does not constitute an inescapable obstacle to the possibility of identifying a writing that reveals a symbiosis of narrative processes between literature and cinema.

Like many authors that we have been mentioning in this study, we believe that vergilian writing at times reflects the narrative techniques of cinema, in particular through the symbiotic experiences of Nouveau Roman and Nouveau Cinéma, in the context of temporality understood by the consciousness of the main character. The vergilian options by processes of parallel narrative assembly, the obsessive meddling of the past in the present by the narrator's mind, the omnipotent and omnipresent recurrence of flashback, and the construction of descriptions that suggest cinematographic shots, are inescapable technical resources for crystallization in Vergílio Ferreira of technical similarities with the cinema. Between the word and the image, the search for the unspeakable takes Vergílio Ferreira to a two-way relationship. At the same time, it looks at two universes, literature and cinema, and never ceases to make the valorization of the former ever more permanent. In the latter, it crosses an itinerary founded on irreducibility, but which leads to contacts of different levels. In a dialogue in the mirror, contemplating the unspeakable that the universe of the cinema symbolizes, the writer built by the word a new space and a new time. In the consciousness of the main 
characters he created, the archetype of his conception of Man in constant questioning, this new space-time connection, between the physical and the metaphysical, redefines the boundaries of being and the borders of writing. In Vergílio Ferreira's world, cinema is also designed as a space for the unspeakable. (Cardoso, L, 2016).

\section{REFERENCES}

[1] António, Lauro, (1995) «Vergílio Ferreira e o Cinema», in Maria Irene Fonseca (org. e coord.) Vergílio Ferreira - Cinquenta anos de vida literária, Actas do Colóquio Interdisciplinar, Porto, Fundação Eng. António de Almeida

[2] Cardoso, Luís Miguel (2016) Literatura e Cinema: o Olhar de Jano. Vergílio Ferreira e o Espaço do Indizível. Lisboa: Edições 70

[3] Ferreira, Vergílio, (1988), Pensar. Lisboa: Bertrand

[4] Ferreira, Vergílio, (1990) Em Nome da Terra. Lisboa: Bertrand

[5] Vergílio Ferreira, (1993) Espaço do Invisível III. Lisboa: Bertrand

[6] Vergílio Ferreira, (1991) Espaço do Invisível II. Lisboa: Bertrand

[7] Ferreira, Vergílio, (1994) Aparição. Lisboa: Bertrand

[8] Listopad, Jorge (1973) «Cinema e ficção: Elementos para a filmagem de Alegria Breve», in Colóquio Letras, $\mathrm{n}^{\circ} 13$

[9] Torres, Mário Jorge, (1995) «A tentação da imagem - A propósito das ficções cinematográficas sobre Vergílio Ferreira», in Maria Irene Fonseca (org. e coord.), Vergílio Ferreira - Cinquenta anos de vida literária, Actas do Colóquio Interdisciplinar, Porto, Fundação Eng. António de Almeida

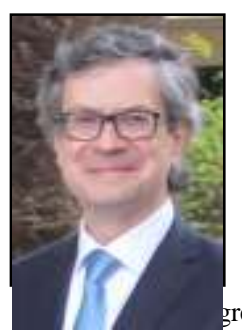

L. Cardoso was born in Viseu (Portugal) in 1969. After concluding the Humanities degree at the Catholic University in 1991, he concluded a Master in Classic Literatures at Coimbra University, in 1996. In 2007 he concluded his $\mathrm{PhD}$ in Modern Languages and Literatures at Coimbra University (Portugal).

After teaching for four years in secondary schools, he began teaching at the Polytechnic Institute of Viseu in 1995 until 2008, when he moved to the Polytechnic re as Adjunct Professor. He was elected Dean of the School of Education and Social Sciences in 2010 until february 2018, completing the two mandates permitted by law. Since 2015 until May, 2018, he was also President of ARIPESE - the Association for Reflexion and Intervention in Higher Schools Polytics. Main interests in teaching and investigation include Science and Communication Languages, Literature and Cinema, and Management of Higher Education Universities. In 2016, he published Literature and Cinema: the look of Janus. Vergílio Ferreira and the space of the unspeakable.

Prof. Dr. Cardoso was the national coordinator for the Bologna Process in Polytechnics in Media and Communication Sciences. He is a member of several international organizations concerning Education, Communication, Comparative Literature, Narratology, Film Studies and Higher Education Management and reviewer of several international journals.

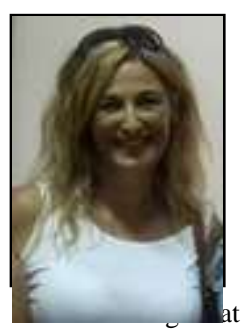

T. Mendes was born in Portalegre (Portugal) in 1968. After concluding the degree in Portuguese and French Teaching at the Evora University in 1991, she concluded a Master in Comparative Literature at Lisboa University in 2001. In 2009 she concluded her PhD in Literary Studies at Lisboa University (Portugal)

After teaching for four years in secondary schools, she began teaching at the Polytechnic Institute of Portalegre in 1996. She has been Coordinator of the Basic this Institute since 2013, and Institutional Coordinator of the Languages Center of the Polytechnic Institute of Portalegre since 2015. Her main interests in teaching and investigation include Science and Communication Languages, Comparative Literature, Children's Literature and Education. In 2015, she published the book Vozes e Silêncio: a Poética do (Des)encontro na Literatura para Jovens. España: Editora Bubok Publishing. Prof. Dr. Mendes was the institutional coordinator of the Portuguese National Education Program and she has published several papers in national and international journals with peer review. She is a researcher member of the
Comparative Studies Center of the Lisboa University and the Interdisciplinary Research and Innovation Coordination of the Polytechnic Institute. 